\title{
Tieteellisesti kiinnostava teos auttaa myös arjessa
}

Anttonen Anneli, Valokivi Heli ja Zechner Minna (2009).

Hoiva. Tutkimus, politiikka ja arki. Vastapaino 2009. 298 sivua.

Harvoin kirjan lukeminen etenee yhtä hartaasti kuin käteeni saamani Hoiva. Paperilaadultaan karkeat ja pienehköllä tekstillä tiiviisti kirjoitetut sivut alkoivat täyttyä reunahuomautuksiin, kysymyksiin ja vasta-argumentteihin.

Kirja on tieteellisesti kiinnostava, mutta siitä löytyy myös arkisiin ratkaisuihin perehtynyttä tietoa niin kotipalveluja kaipaavalle omaishoitajalle kuin kunnallispoliitikollekin. Moni "miksi ihmeessä” -kysymys löytää sivuilta perustelun, vaikka se ei palveluja tarvitsevaa tai poliitikkoa tyydyttäisikään.

Kirja alkaa hoiva -käsitteen analyysilla ja kolmeen vuosikymmeneen ulottuvalla (1970 2000) historiallisella katsauksella. Naistutkimuksen näkökulman valitsemista perustellaan terveen kriittisesti. Ennen näkymätön ja pääasiassa naisten toteuttama hoiva saa näkyvät puitteet ja tulee päteväksi tutkimuskohteeksi. Tässä kohdin lukijana intoudun väittelemään, en kirjoittajien, vaan ansiokkaasti ja napakasti esitettyjen teorioiden kanssa. Naistutkimus on mitä ilmeisimmin oikea viitekehys tarkastelulle.

Teoreettisesta lähtökohdasta edetään yhteiskunnallisiin ja käytännöllisiin kysymyksiin. Hoivan tarkastelu rajataan lasten, vammaisten ja vanhusten parissa tehtyyn hoivaan. Esimerkit välittävät yksilöllisiä koke- muksia ja kuvaavat yhteiskunnallisia ratkaisuja. Kirjassa puututaan myös hoivatyösiirtolaisuuteen ja harmaan hoivatyön eettisiin ilmiöihin.

Hoivapolitiikan keskeisistä kysymyksistä käsitellään vanhusten ja vammaisten subjektiivista oikeutta hoivaan ja henkilökohtaiseen apuun. Lisäksi tarkastellaan pohjoismaiden hyvinvointivaltion mallia, pienten lasten hoivan kehittymistä universaalipalveluksi. Sillä tarkoitetaan lapsen henkilökohtaista oikeutta päivähoitoon, joka on riippumaton vanhempien tuloista tai siitä, ovatko vanhemmat työelämässä. Omaisten asema hoivapalvelujen tuottamisessa tarkastellaan myös monipuolisesti.

Julkinen valta vaikuttaa eri tavoin hoivan tuottamiseen palvelujen, rahallisten etuuksien ja hoivavapaiden muodossa. Vaihtoehtojen olemassaolo mahdollistaa autonomian ja valitsemisen, ainakin periaatteessa. Kotitalousvähennykset ja palvelusetelit ovat tulleet jäädäkseen. Verotuksessa vähennyskelpoisten palvelujen kirjo tulee laajenemaan, palveluseteleiden käytön odotetaan lisäävän kilpailua ja tarjontaa.

Mielenkiintoisen ja konkreettisen ulottuvuuden hoivan maailmaan avaavat luvut, joissa kuuluu hoivaajien ja hoivaa tarvitsijoiden äänet. Esiin poimitut kokemukset kuvaavat hoivalle annettuja merkityksiä ja sitä, mitä kulttuurisia normeja tai sukupuolittuneita odotuksia siihen liitetään. Ihmisten yhteinen historia, moraalinen tunto tai rakkaus on yhtä lailla omaishoivan taustalla kuin käytännölliset järjestelyt tai kunta- ja palveluliitoksista aiheutuneet pidentyneet välimatkatkin.

Näyttää siltä, että taloudellinen niukkuus on vaatinut luovia poliittisia ratkaisuja, jotka ovat lisänneet ihmisten valinnan mahdollisuuksia, autonomia ja sen myötä inhimillisempää hoivapolitiikkaa.

\section{Annu Haho}

\section{Sinä kriittinen ja asiantunteva lukija}

Lukukokemukset ja lukemisen herättämät ajatukset ansaitsevat tulla jaetuiksi. Kun innostut jostakin Aikuiskasvatuksen lukijoita kiinnostavasta kirjasta - kotimaisesta tai ulkomaisesta - tarjoa siitä myös lehteen arviosi. Ota lehden lukijat mukaan keskustellessasi teoksen kanssa! Aikuiskasvatus haluaa seurata niin alan uutuuskirjallisuutta kuin teemoihin liittyvää kirjallisuutta ja saada asiantuntemuksesi ja lukukokemuksesi näin laajempaan käyttöön! 